\author{
Olga Gerlich \\ UNIVERSITY OF WROCŁAW
}

\title{
State Immunity or State Impunity? Human Rights and State Immunity Revisited in the ICJ's Judgment on the Case of the Jurisdictional Immunities of a State
}

\author{
State immunity is not a right but rather a prerogative or privilege; \\ it cannot be upheld in a way that leads to manifest injustice ${ }^{1}$
}

In its recent judgment on the case of the Jurisdictional Immunities of the State between Germany and Italy ${ }^{2}$, the International Court of Justice dealt with the issue of the relationship between the immunity of states before national courts, and the protection of fundamental human rights. One of the most relevant matters presented by the parties to the court involved the question of the binding force of the ius cogens exception to state immunity. The ICJ rejected this concept, stating that immunity must be granted to the perpetrator state even in cases of severe human rights violations amounting to violations of peremptory norms of international law. Although this decision was largely anticipated, the Court's formalistic approach was met with a wave of criticism from human rights advocates. This paper seeks to evaluate the Court's line of argumentation, analyze the major points of critique of the decision and consider its impact on public international law.

\section{Factual background}

The case focused on the atrocities committed against Italian citizens by the German Reich between 1943 and 1945. These included massacres, deportations and submission of the civilian population in Italy to forced labour. The Republic of Germany undertook a number of legislative efforts to compensate the victims of the national so-

1 Dissenting Opinion of Judge Trindade - the case of the Jurisdictional Immunities of the State between Germany and Italy.

2 Judgment of 3 February 2012 on the case of the Jurisdictional Immunities of the State between Germany and Italy. 
cialist regime. They included the Federal Compensation Law of 1953, agreements between the Republics of Germany and Italy of 1961, as well as the establishment of the "Remembrance, Responsibility and Future Foundation" of 2000 in the federal law. Still, many Italian victims did not qualify for any of these reparation programs on various grounds.

The direct reason for bringing the dispute before the ICJ were the proceedings commenced by the Italian Courts. In 1998, Mr. Luigi Ferrini, an Italian national arrested and deported to Germany in 1944, instituted proceedings before the Court of Arezzo in Italy. After the case was considered in two instances, the Italian Court of Cassation issued a final judgment stating that Mr. Ferrini should be granted compensation from the German State. Following this judgment, the Italian Court of Cassation confirmed its jurisdiction over the claims against the German Republic in a case concerning Giovanni Mantelli and others as well as in the proceedings brought against Mr. Milde, a member of the special division of German armed forces responsible for the massacres in Civitella, Val di Chianna, Cornia and San Pancrazio.

The case before the ICJ was further based on proceedings brought before Italian courts involving Greek nationals. The families of victims of the massacre at the Greek village of Distomo obtained favorable judgments in proceedings against Germany before Greek courts, which awarded them compensation. However, the judgments could not be executed due to the provision of the Greek Code of Civil Procedure requiring the authorization of the Minister of Justice to enforce a decision against a foreign state. After unsuccessful attempts before German courts, the victims sought enforcement in Italy. It was granted in 2005 by the Court of Appeal in Florence and confirmed by the Court of Cassation. Pursuant to the decision, the claimants filed for measures of constraint to be taken against Villa Vigoni, a property of the Republic of Germany in Italy.

\section{State Immunity}

State immunity protects a state and its property from the exercise of jurisdiction by foreign domestic courts. It is divided into jurisdictional immunity which protects a state in administrative, civil and criminal proceedings, and enforcement immunity which covers the measures of enforcement of the judicial decisions ${ }^{3}$. Sovereign immunity is distinct from immunity of heads of states and diplomatic immunity, although all those types of immunity are closely related. State immunity is largely accepted as part of customary international law, which was confirmed in the ICJ's judgment in the case of Jurisdictional Immunities.

3 P. T. Stoll, State Immunity, "Max Planck Encyclopedia of Public International Law”, 2011. 
The concept of state immunity is drawn from the principles of the sovereignty of states and their equality which is reflected in the notion "par in parem non habet imerium" formulated by Bartolus de Saxoferrato as far back as 1354 . With time, state immunity was regarded less and less as an absolute privilege. Several restrictions to the principle have been accepted by the international community. Firstly, immunity can be waived with the explicit consent of a state (waiver of immunity). Secondly, state immunity covers acta iure imperii exclusively, sovereign acts of state, which are to be distinguished from the notion of acta iure gestionis, covering the realm of the commercial activities of a state. The other possible limitation to state immunity would be applicable in cases of violations of human rights. This limitation was first discussed in the Pinochet Case before the UK House of Lords and in the Arrest Warrant case before the ICJ. However, the immunity of heads of states was the central issue in these disputes and the relevance of their effects on state immunity is disputable. The question was recently raised in the Al-Adsani case before the European Court of Human Rights, dealing with state immunity from the alleged violation of the prohibition of torture.

\section{The Ius Cogens Exception}

The idea that international law shall not accord immunity before domestic courts to a state which commits violations of fundamental human rights is based on the theory of the normative hierarchy of international law. Art. 53 of the Vienna Convention on the Law of Treaties ${ }^{4}$ provides that a peremptory norm of general international law, accepted and recognized by the international community of States as a whole and from which no derogation is permitted (ius cogens), prevails over any norm of international law which is inconsistent with it. As jurisdictional immunity does not have the status of a peremptory norm, it ranks lower in the hierarchy of international law and must give way to a ius cogens norm when such a situation arises. In the discussed case, the power of ius cogens to derogate colliding norms would extend beyond the direct inconsistency of obligations under international law and would also include any overriding obligations that impair the effectiveness of the norm 5 . The proposition of primacy of ius cogens over state immunity finds as much support ${ }^{6}$ as opposition among scholars. An animated academic

\footnotetext{
4155 U.N.T.S. 331, 8 I.L.M. 679.

5 A. Mills, K. Trapp, Smooth Runs the Water where the Brook is Deep: The Obscured Complexities of Germany v Italy, "Cambridge Journal of International and Comparative Law" vol. 1, 2012, p. 153,160; M. Karagiannakis, State Immunity and Fundamental Human Rights, "Leiden Journal of International Law" vol. 11 no. 1, 1998, p. 9,19.

6 Cf. A. Orakhelashvili, State Immunity and Hierarchy of Norms: Why the House of Lords Got It Wrong, "European Journal of International Law" vol. 5, 2007, p. 955; L. McGregor, Torture and State Immunity: Deflecting Impunity, Distorting Sovereignty, "European Journal of International Law” vol. 5, 2007, p. 903; A. Belsky, M. Merva, N. Roht-Ariaza, Implied Waiver under
} 
discussion of this concept evolved after the delivery of a judgment in the Al-Adsani case $^{7}$. As the concept of the primacy of ius cogens over state immunity was rejected by the Court with a small majority (9-8), it is not seen as a final resolution of the dispute.

Apart from the argument of the derogating power of ius cogens, the supporters of the concept emphasize the effect of peremptory norms for state recognition ${ }^{8}$. As laid down in Art. 41 of the ILC's Articles on State Responsibility ${ }^{9}$, states are precluded from recognizing as lawful any situation which is an outcome of a breach of an ius cogens norm. Thus, granting immunity to a state in cases of violations of fundamental human rights would amount to recognizing such a situation and assisting in the upholding of it.

Another argument implies the existence of the so-called implied waiver of immunity ${ }^{10}$. It is based on the fact that immunity before domestic courts is not absolute and can be waived by the state. This approach is explained by a two-fold argumentation. Firstly, it is assumed that the state by implication waives its immunity by committing an act which constitutes a violation of a ius cogens norm of international law. Secondly, by ratifying a treaty on human rights provisions, states bound themselves to providing effective remedies for individuals in cases of violations of these rights. Under such circumstances, the obligation to protect human rights translates into an implied waiver of immunity before national courts. It must be noted that the general idea of a waiver of immunity was heavily criticized and declared to be unconvincing ${ }^{11}$.

\section{The Judgment}

In the judgment delivered on 3 February 2012, the ICJ decided in favor of the Applicant. It stated that Italy failed to respect Germany's immunity under international law in three instances: (i) by allowing the civil claims based on violations of international humanitarian law committed between 1943-1945 to be brought against Germany before Italian Courts; (ii) by taking measures of constraint against Villa Vigoni, a property of the German state in Italy; and (iii) declaring as enforceable the decisions of Greek courts, which were based on violations of international humanitarian law in Greece. During

the FSLA: A Proposed Exception to Immunity for Violations of Peremptory Norms of International Law, "California Law Review" vol. 77, 1989, p. 365; For opposing views $c f$. L.M. Caplan, State Immunity, Human Rights and Ius Cogens. A Critique of the Normative Hierarchy Theory, "American Journal of International Law" vol. 972003,p.741; H. Fox, The Law of State Immunity, Oxford 2005.

7 Al-Adsani v. United Kingdom 2001; Appl. no. 35763/97, ECHR 752.

8 A. Orakhelashvili, op.cit., p. 967.

9 Articles on Responsibility of States for Internationally Wrongful Acts, UN Doc. A/56/10, adopted by the International Law Commission at its fifty-third session (November 2001).

10 V. Belsky, M. Merva, N. Roht-Ariaza, op.cit.

11 J. Bröhmer, State Immunity and The Violation of Human Rights, Hague 1997, p.190-193; Karagiannakis, op.cit., p. 21. 
the proceedings, Italy claimed as part of its defence that international law had developed certain exceptions to the principle of sovereign immunity, applicable to the case at hand. The derogations which they invoked, and which were subsequently rejected by the Court, were the 'territorial tort principle' and the exception based on the particular nature of violations of fundamental human rights, the subject-matter of the case ${ }^{12}$.

The Court examined Italy's argument in three strands that, according to their claims, would cumulatively result in an exception to the rule of state immunity ${ }^{13}$. Firstly, the acts giving rise to the Italian claims constituted grave violations of humanitarian law, amounting to war crimes or crimes against humanity. Secondly, the rules of law which were violated constitute peremptory norms of international law. Thirdly, the lack of any other form of redress rendered the exercise of jurisdiction by the Italian court to be a measure of last resort for the Italian victims.

\section{Gravity of violations}

In the first strand, the ICJ denied customary status to the public international law norm under which, as claimed by Italy, state immunity does not apply where a claim concerns redress for alleged violations of international human rights or humanitarian law. According to the Court, apart from the decisions of the Italian and Greek courts, there is almost no example of state practice to support this claim. In order to draw this conclusion, the Court carefully analyzed the judgments of domestic courts involving the question of state jurisdiction in cases of alleged human rights violations ${ }^{14}$, as well as the relevant treaty law ${ }^{15}$. After considering national case law, the Court concluded that states were likely to support the notion of state immunity and found almost no proof of practice to the contrary. With regard to treaty law, the United Nations Convention on Jurisdictional Immunities of States and Their Property ${ }^{16}$ was the subject of thorough examination by the Court. Violations of human rights were explicitly discussed as a possible exception to state immunity, yet this was not included in the final draft of the Convention as the matter was "not yet ripe" for codification ${ }^{17}$.

This approach was criticized by Judge Yusuf in his dissenting opinion and described by him as a "cherry-picking" approach ${ }^{18}$. Given the limited amount of applicable case law and

12 Judgment on the case of the Jurisdictional Immunities of the State between Germany and Italy, para. 64-108.

13 Ibidem, para. 80.

14 Ibidem, para. 83.

15 Ibidem, para. 88-89.

16 UN Doc. A/RES/59/38.

17 Judgment on the case of the Jurisdictional Immunities of the State between Germany and Italy, para. 89.

18 Dissenting Opinion of Judge Yusuf - the case of the Jurisdictional Immunities of the State between Germany and Italy, para. 23. 
the conflicting domestic decisions on application of this exception, the arguments of the Court were rather unpersuasive as the other exceptions to state jurisdiction were accepted by it as part of customary international law, despite the similar circumstances of their application. Moreover, as the applied approach was based on a comparison of the number of reasons 'for' and 'against' the exception, it is hard to substantiate the Court's decision not to take into proper consideration the decisions of the Italian and Greek courts ${ }^{19}$.

Having dealt with the question of the existence of customary international law supporting the argued exception to the principle of state immunity, the Court turned to a more systematic argument regarding the consequences of the ius cogens norms involved in the case.

\section{State immunity as a procedural rule}

The Court employed clear and logical reasoning. The question of immunity is preliminary in nature, thus a domestic court must determine if the immunity is granted to a state, before it proceeds to the merits of the case. However, if the question of immunity were dependent upon the determination of whether human rights or humanitarian law violations had occurred, the court would be compelled to inquire into the merits of the case, thus exercising its jurisdiction ${ }^{20}$.

The Court established that the arguments of the Parties relied on the premise of the existence of a conflict between the violation of peremptory norms of international law, on the one hand, and the rules of state immunity on the other. In the opinion of the Court, no such conflict exists as these norms address entirely different matters ${ }^{21}$. While state immunity constitutes a "rule essentially procedural in nature", the peremptory norms are of a substantial character ${ }^{22}$. The distinction between procedural and substantial rules is not new to the jurisprudence of the $\mathrm{ICJ}^{23}$. It has also been drawn upon in decisions of regional ${ }^{24}$ and domestic courts ${ }^{25}$ dealing with the issue of the alleged conflict between ius cogens norms and immunity of state, and has also been advanced in its legal literature ${ }^{26}$.

However, it is far from obvious which norms of international law are to be of "procedural character". Some scholars, like Stefan Talmon, have attempted to compile a catalogue

19 Ibidem, para. 24.

20 Judgment on the case of the Jurisdictional Immunities of the State between Germany and Italy, para. 82.

21 Ibidem, para. 93.

22 Ibidem.

23 In the Arrest Warrant Case the ICJ held that "Immunity from criminal jurisdiction and individual criminal responsibility are quite separate concepts. While jurisdictional immunity is procedural in nature, criminal responsibility is a question of substantive law.".

24 In the $A l-A d s a n i$ case involving the freedom from torture the ECtHR decided that state immunity is "to be seen not as qualifying a substantive right but as a procedural bar on the national courts' power to determine the right."

25 Jones v. Ministry of Interior of the Kingdom of Saudi Arabia, 1 AC 270, para. 44-45.

26 H. Fox, op.cit., p.525. 
of such norms ${ }^{27}$. Others, like A. Orkasheshvili, deny even the possibility of categorizing the norms of international law, as no clear criteria has hereto emerged upon agreement of states ${ }^{28}$. Moreover, the usefulness of this distinction for the practice of international law has also been the subject of academic disputes and even Greece, the non-partisan intervener, claimed the distinction to have "no logical or, still less legal consequence"29.

Apart from those contestations, another question arises as to whether the employment of this strict "substantial-procedural" distinction, which results in barring proceedings from providing a remedy for violations of human rights, was appropriate in terms of being incompatible with the universally accepted idea of justice.

\section{The "Last resort" argument}

The last Italian argument implied that Germany was to be denied immunity as the victims were deprived of any remedies to preserve the realization of their individual right to reparation for grave violations of human rights and humanitarian law.

According to the Court, this argument was also flawed. Once again, the "substantial-procedural" was employed. Immunity before foreign domestic courts is to be regarded as a totally separate question from the issue of obligations arising from its responsibility under international law ${ }^{30}$. Moreover, the Court found no basis in customary international law for requiring the existence of alternative means of securing redress for a state's entitlement to immunity ${ }^{31}$. In any case, following the Italian argument, the ICJ found a difficulty in the practical realization of such an approach. The mere fact that the victims received no redress is not decisive, as long as the inter-state discussions were still ongoing and were showing the prospect of success ${ }^{32}$. In such cases, the right to immunity shall prevail. The problem lies in determination of the point when the prospect of such an outcome ceases to exist.

In his dissenting opinion, Judge Trindade elaborated on the problem of the notion of the right to access to justice presented to the parties in the dispute ${ }^{33}$, which was not given

27 Such a catalogue would include e.g. rules on the establishment and composition of a court, its jurisdiction, admissibility of claims or application, rules concerning preliminary objections, implementation of international responsibility. Moreover, according to the author the "rules of procedural nature" are not identical in content with rules of procedure or procedural law; S. Talmon, Ius Cogens after Germany v. Italy, Substantive and Procedural Rules Distinguished, "Bonn Research Papers on International Law" no. 4, 2012.

28 A. Orakhelashvili, op.cit., p. 968.

29 Written Statement of the Hellenic Republic.

30 Judgment on the case of the Jurisdictional Immunities of the State between Germany and Italy, para. 100.

31 Ibidem, para. 101.

32 Ibidem, para. 102.

33 Dissenting Opinion of Judge Trindade - the case of the Jurisdictional Immunities of the State between Germany and Italy, para. 73. 
much attention in the judgment. He observed that the parties understood this in very different terms. Germany construed it narrowly, arguing it should be restricted to access to the judicial system of the forum state without discrimination and with full procedural rights ${ }^{34}$. Italy argued that it comprises both the right to establish the judicial proceedings and the individual right to reparation ${ }^{35}$. Judge Trindade associates this disagreement with the bigger problem of understanding the notion ${ }^{36}$. Following the assertion of the ECtHR in the Hornsby v. Greece $\mathrm{Case}^{37}$, he contends that the right to receive reparation should be seen as one of the essential components of the right to access to justice, providing its full realization.

\section{Positivism versus Human Rights?}

When considering Germany's claim to immunity, the Court employed a positivistic, source-oriented attitude which is deeply rooted in the tradition of international law. However, it must be observed that this formalistic attitude contravenes some basic concepts of human rights and humanitarian law such as the right to effective remedy, right to compensation for damages resulting from serious breaches of humanitarian law or protection from denial of justice.

This calls into question whether this approach is appropriate in cases seeking redress for violations of fundamental human rights. At first glance, it could be stated that a banal issue of $\operatorname{logic}^{38}$, considered in an a priori position, in disregard of its consequence and purpose, led to a contravention of fundamental values, and in fact of injustice. This fact was a particular point of criticism of the supporters of the more value-oriented view of international law, also within the Court itself (see the dissenting opinion of Judges Trindade and Yusuf).

International law is state centered. This is a fact. Although new actors emerge in the arena of international relations, the position of states as the main actors remains unchanged. The principle of state immunity, created to safeguard states' special position in international relations, stems from this state - centric approach. But it is also a fact that the extent of state immunity has evolved. From its original position as an absolute, it has shrunk to immunity restricted by numerous exceptions. Another remark on the evolution of international law would be that the weight that was once attached to the prerogatives of states, as projected in Jean Bodin's vision of state sovereignty, has

34 Reports of Judgments and Decisions 1997-II - Judgment of 19 March 1997.

35 Dissenting Opinion of Judge Trindade - the case of the Jurisdictional Immunities of the State between Germany and Italy, para. 77 .

36 Ibidem, para. 221.

37 Reports of Judgments and Decisions 1997-II - Judgment of 19 March 1997.

38 Judgment of 3 February 2012 on the case of the Jurisdictional Immunities of the State between Germany and Italy, para. 82. 
moved towards their obligations as members of the international community. The decision to uphold state immunity in cases of human rights violations, grounded upon formalistic grounds, could be seen as a step towards the fossilization of the state - orientated concept of international law. Some practical difficulties in supporting the position of denial of state immunity in cases of human rights violations have been pointed out. A. Orakhelashvili identifies the deterioration of bilateral relations between the forum state and the perpetrator state among the possible risks as well as the flood of litigation when the victims come to the relevant forum state to sue the perpetrators ${ }^{39}$. These would justify considering the approach applied by the Court as a "conflict avoidance technique", resorted to in order to avoid the questions of normative hierarchy ${ }^{40}$, which along with "excessively formalistic" 41 or "illusory" are only a few of the many adjectives used to describe the attitude taken.

\section{Conclusions}

In 1933, Walter Wheeler Cook, author of numerous publications on the methodology of law, argued that the "substance-procedure" distinction has no "necessary" content; that there is no objective line which must be "discovered" and indeed, that different lines are drawn in different contexts ${ }^{42}$. Implying that this had been the Court's assumption, one could conclude that the Court had discovered the line regarding Jurisdictional Immunities of the State and decided that state immunity should prevail. The paper does not aim to dispute this decision, as it is appreciated that a number of factors based on the facts of the case were considered by the Court.

However, it could be argued that the Court could have adopted a different approach, namely to preserve state immunity on the basis of an a priori "substance-procedure" distinction, disregarding the importance and normative value of the principles at stake. The author of this paper would rather suggest a case-by-case approach which would allow a drawing of the line between the substance and the procedure. Such a line would be construed upon a balancing of the values at issue, which would be more appropriate. Referring to the title of the paper, "in practice immunity leads to de facto impunity", as observed by Judge van den Wyngaert, an ad hoc Judge in the Arrest Warrant Case ${ }^{43}$. Applying an in casu approach to the "substance-procedu-

39 Orakhelashvili immediately rejects the argument of both risks stating that no firm evidence in favor of the first can be provided, while the avoidance of the latter is safeguarded by the forum non conveniens principle.

40 P. Webb, Human rights and the Immunities of State Officials, [in:] Hierarchy of International Law: the Place of Human Rights, ed. E. de Wet, J. Widma, Oxford 2012, p. 300, 308.

41 L. McGregor, op.cit., p. 911.

42 Cit. per: A. Mills, K. Trapp, op.cit., p.163.

43 Dissenting Opinion of Judge van der Wyngaert the case of the Arrest Warrant, para. 34. 
re" distinction would help to avoid such controversy as it would allow for a balancing of the competing interests and arguments, previously barred on notional and formalistic grounds. Furthermore, it would not contravene the idea of distinction itself as its functions and content are largely justified, which has already been demonstrated.

\section{Summary}

\section{State Immunity or State Impunity? Human Rights and State Immunity Revisited in the ICJ's Judgment in the Case of the Jurisdictional Immunities of a State}

The paper aims to comment on the judgment of the International Court of Justice of 2nd February 2012 in the case of Jurisdictional Immunities of the State between Germany and Italy from the perspective of the problem of jurisdictional immunity. In its decision concerning compensation for atrocities suffered by Italian citizens during World War II granted by Italian courts against the German State as well as the execution of the analogical decisions of Greek courts, the International Court of Justice upheld the immunity of the German State. The compensation sought by the plaintiffs in the national proceedings was to redress massacres on the civil population, deportations and forced labour. In its decision the Court analyzed the exception proposed by Italy in three strands which, according to the Respondent, cumulatively would result in an exception to the rule of state immunity. Firstly, the acts giving rise to the Italian claims constituted grave violations of humanitarian law; secondly, the rules of law violated constitute peremptory norms of international law; thirdly, no other form of redress was available rendering the exercise of jurisdiction by the Italian court to be a measure of a last resort for the victims.

KEYwords: International Court of Justice, state immunity, human rights 